\title{
FORMULASI DAN UJI AKTIVITAS ANTIBAKTERI Streptococcus mutans DARI SEDIAAN MOUTHWASH EKSTRAK DAUN JAMBU BIJI (Psidium guajava L.)
}

\author{
Fitri Handayani*, Reksi Sundu, Ria Mareta Sari \\ Akademi Farmasi Samarinda \\ *Corresponding author email : sausanrukan@yahoo.co.id
}

\begin{abstract}
Guava leaves have been used as antidiarrhea, antioxidant, aniinflamation, and antimicrobial. The results of its preliminary phytochemical analysis showed the presence of tannins, flavonoids, steroids and saponins. This leaves also contain essential oil such as sineol. Utilization of guava leaves as a mouthwash preparation is an alternative to replace the mouthwash preparations which generally contain antiseptic form of alcohol that can lead to oral cancer. This experiment formulated the extract of guava leaves into mouthwash that fulfill the physical requirements and determine the differences of antimicrobial activity against the growth of Streptococcus mutans with concentration of extract : 2,5\%; $3 \%$ and 3,5\%. Antibacterial acivity test was using MHA media with agar diffusion method. Physical requirement test included organoleptic, $\mathrm{pH}$ and viscosity test. The result showed that the mouthwash preparation of guava leaves extract has a $\mathrm{pH}$ value outside the range of the optimum growth of bacteria $(\mathrm{pH}=5)$. The viscosity of the mouthwash was 1,328-1,347 cP. The antibacterial activity of Streptococcus mutans on F1 has inhibition zone of 3,15 mm, F2 (3,83 mm) and F3 (4,32 mm). It was concluded that the extract of guava leaves on concentrations of 2,5\%; 3\% and 3,5\% can be formulated as mouthwashes. The mouthwash fulfilled the physical requirement test such as $\mathrm{pH}$, viscosity and organoleptic test and can inhibit the growth of Streptococcus mutans.
\end{abstract}

Keyword: formulation, mouthwash, guava leaves, Streptococcus mutans

\begin{abstract}
ABSTRAK
Daun jambu biji memiliki khasiat sebagai antidiare, antioksidan, antiinflamasi dan antimikroba. Hasil fitokimia ekstrak daun jambu biji menunjukkan bahwa tanaman ini mengandung tanin, flavonoid, steroid, dan saponin. Selain itu ekstrak daun jambu biji juga mengandung minyak atsiri yang kaya akan sineol. Pemanfaatan daun jambu biji sebagai sediaan mouthwash merupakan suatu alternatif untuk mengganti sediaan mouthwash yang pada umumnya mengandung antiseptik berupa alkohol yang dapat memicu terjadinya kanker mulut. Penelitian ini memformulasikan ekstrak daun jambu biji menjadi sediaan mouthwash yang memenuhi persyaratan fisik dan mengetahui perbedaan aktivitas antibakteri terhadap pertumbuhan Streptococcus mutans dengan variasi konsentrasi ekstrak 2,5\%,3\%, dan 3,5\%. Uji aktivitas antibakteri menggunakan media MHA dengan metode difusi agar. Uji persyaratan fisik meliputi uji organoleptis, uji pH, dan uji viskositas. Hasil penelitian menunjukkan bahwa sediaan mouthwash ekstrak daun jambu biji mempunyai $\mathrm{pH}$ di luar range pertumbuhan optimum bakteri, yaitu 5. Viskositas sediaan mouthwash sebesar 1,328-1,347 cP. Aktivitas antibakteri Streptococcus mutans pada F1 menghasilkan zona hambat sebesar 3,15 mm, F2 sebesar 3,83 mm, dan F3 sebesar 4,32 mm. Penelitian ini dapat disimpulkan bahwa ekstrak daun jambu biji konsentrasi 2,5\%, 3\% dan 3,5\% dapat diformulasikan dalam bentuk sediaan mouthwash. Sediaan mouthwash memenuhi persyaratan fisik meliputi, uji pH, uji viskositas, uji organoleptis dan dapat menghambat pertumbuhan bakteri Streptococcus mutans.
\end{abstract}

Kata kunci: formulasi, mouthwash, daun jambu biji, Streptococcus mutans

Submitted on:5 April 2017

Accepted on: 5 Desember 2017

DOI: https://doi.org/10.25026/jsk.v1i8.62 


\section{PENDAHULUAN}

Penyakit karies gigi dan jaringan pendukung gigi (periodontal) umumnya disebabkan oleh plak gigi, yang sampai saat ini masih menjadi masalah utama dalam bidang kesehatan mulut dan gigi.Plak gigi adalah lengketan yang berisi bakteri dan produk-produknya yang terbentuk pada permukaan gigi [1]. Bakteri yang berperan penting dalam pembentukan plak gigi adalah bakteri yang mempunyai kemampuan untuk membentuk polisakarida ekstraseluler, yaitu jenis Streptococcus. Bakteri Streptococcus yang ditemukan dalam jumlah besar pada plak penderita karies adalah Streptococcus mutans [2]. Bakteri ini dapat membentuk koloni yang melekat erat pada permukaan gigi [1].

Hasil Survei Kesehatan Rumah Tangga (SKRT) yang dilakukan Departemen Kesehatan menyebutkan, penyakit gigi dan mulut menduduki urutan pertama dengan jumlah 60 persen dari 10 penyakit terbanyak yang diderita masyarakat. Hasil riset kesehatan dasar nasional yang dilakukan Departemen Kesehatan pada tahun 2013 diketahui bahwa adanya peningkatan prevalensi terjadinya karies aktif pada penduduk Indonesia dibandingkan tahun 2007 lalu, yaitu dari 43,4 \% (2007) menjadi 53,2 \% (2013). Penduduk dengan masalah gigimulut dan menerima perawatan atau pengobatan dari tenaga kesehatan gigi adalah $29,6 \%$. dan $21,05 \%$ permasalahan gigi dan mulut tersebut diderita pada golongan usia 10-24 tahun atau dapat dikategorikan sebagai remaja [3].

Perlu adanya suatu aktifitas guna menjaga kebersihan serta kesehatan mulut dan gigi.Untuk mencegah tumbuhnya mikroorganisme secara sempurna, maka para pakar di bidang periodontologi mengadakan penelitianpenelitian menggunakan antiseptik yang mempunyai sifat antibakteri.Kebanyakan antiseptik dikemas dalam bentuk obat kumur.Akan tetapi penggunaan antiseptik dalam obat kumur dewasa ini diduga dapat berefek karsinogenik terhadap penggunanya.Hal ini didukung dari hasil penelitian Prof. McCullough dan Farah dalam Australian of Dental Journal (2008) [4] yang menyatakan bahwa pemakaian mouthwash dengan kandungan antiseptik berupa alkohol dapat memicu terjadinya kanker mulut.

Bahan alternatif yang dapat digunakan untuk mencegah karies gigi adalah ekstrak daun jambu biji (Psidium guajava L.).Daun jambu biji diketahui memiliki khasiat sebagai antidiare, antioksidan, antiinflamasi dan antimikroba.Hasil fitokimia ekstrak daun jambu biji menunjukkan bahwa tanaman ini mengandung tanin, flavonoid, steroid, dan saponin.Selain itu ekstrak daun jambu biji juga mengandung minyak atsiri yang kaya akan sineol. Senyawasenyawa tersebut diketahui memiliki aktivitas sebagai antibakteri [5]. Kandungan senyawa tanin dan minyak atsiri dalam ekstrak daun jambu biji varian putih memiliki komposisi yang lebih besar bila dibandingkan dengan ekstrak daun jambu biji varian merah [6]. Dari penelitian yang telah dilakukan oleh Adnyana (2004) [7] diketahui bahwa ekstrak daun jambu biji varian putih menunjukkan aktivitas antibakteriyang lebih kuat dibandingkan ekstrak daun jambu biji varian merah untukmenghambat pertumbuhan Shigella dysenteriae, Escherichia coli, Shigella flexneri, dan Salmonella typhi. Telah diketahui pula bahwaekstrak daun jambu biji dapatmenghambat pertumbuhan bakteri Grampositif penyebab karies gigi yakni Streptococcus mutans dengan kadar hambat minimal sebesar 2\% dan kadar bunuh minimal sebesar $3.5 \%$ [8]. Berdasarkan uraian tersebut, maka dilakukan penelitian formulasi dan uji 
aktivitas antibakteri Streptococcus mutans dari sediaan mouthwash ekstrak daun jambu biji (Psidium guajava L.).

\section{METODE PENELITIAN}

Alat

Stamper, mortir, alat gelas (Pyrex, Iwaki), kertas saring, neraca analitik (OHAUS), indikator $\mathrm{pH}$ Universal, viskometer Ostwald (Pyrex), Autoklaf (Speedy Autoclave tipe Vertical model HL-340), cawan petri, hot plate, inkubator (Jouan tipe IG 150), magnetic stirer, mikro pipet.

\section{Bahan}

Air suling, daun jambu biji, etanol 95\%, sorbitol, peppermint oil, gliserin, mouthwash komersial, media Mueller Hinton Agar (MHA), Larutan Mc. Farland, paper disc.

\section{Prosedur Penelitian}

\section{Ekstraksi Daun Jambu Biji}

Ekstraksi menggunakan cara maserasi dengan menggunakan pelarut etanol 95\%. Sampel ditimbang, kemudian dimasukkan ke dalam wadah kaca dan direndam dengan etanol 95\% (sebanyak $10 \mathrm{x}$ berat serbuk) selama 6 jam pertama sambil sesekali diaduk, kemudian didiamkan selama 18 jam,lalu ditutup. Maserat dipisahkan dengan cara penyaringan. Proses penyarian diulangi sekurang-kurangnya dua kali dengan menggunakan pelarut dengan jenis dan jumlah yang sama. Kemudian semua maserat dikumpulkan dan kemudian diuapkan hingga diperoleh ekstrak kental.

\section{Formulasi Sediaan mouthwash}

Formulasi sediaan mouthwash didasarkan pada penelitian Pradewa(2008) [9] dengan beberapa variasi konsentrasi ekstrak yakni $2,5 \%$,
$3 \%$ dan 3,5\%. Komposisi formula mouthwash dapat dilihat pada tabel 1.

Cara Pembuatan Mouthwash

1) Dimasukkan ekstrak ke dalam mortir

2) Ditambahkan gliserin 3 gdigerus hingga homogen

3) Ditambahkan sorbitol 10 glalu digerushingga homogen

4) Ditambahkan air suling secukupnyakedalam mortir lalu digerus hingga bisa dituang

5) Disaring dan dimasukkan kedalam botol kemudian ditambahkan air suling hingga $100 \mathrm{ml}$

6) Ditambahkan peppermint oil 3 tetes ke dalam botol lalu di kemas

3. Evaluasi sediaan mouthwash

a. Pengamatan Organoleptis

Sediaan diamati selama 3 minggu penyimpanan meliputi aroma, warna, dan rasa.

\section{b. Uji pH (Derajat Keasaman)}

Pemeriksaan $\mathrm{pH}$ dilakukan dengan menggunakan kertas $\mathrm{pH}$ universal.Kertas $\mathrm{pH}$ universal dicelupkan ke dalam mouthwashselama beberapa menit kemudian dicocokan dengan warna indikator. Pengukuran dilakukan pada suhu ruangan. Nilai $\mathrm{pH}$ suatu medium sangat mempengaruhi jenis bakteri yang dapat tumbuh. Kebanyakan bakteri mempunyai $\mathrm{pH}$ optimumyaitu sekitar 6,57,5 [10]. Oleh karena itu, nilai $\mathrm{pH}$ dari formulasi sediaan mouthwash ekstrak daun jambu biji harus berada di luar range nilai $\mathrm{pH}$ optimum pertumbuhan bakteri karena sifat formulasi sediaan mouthwash yang diinginkan bersifat antibakteri. Selain itu, $\mathrm{pH}$ pada mouthwash berkisar antara 5,71-5,98 [9].

c. Uji Viskositas

Uji viskositas sediaan menggunakan viskometer Ostwald.Sediaan sebanyak 50 
ml dimasukkan melalui tabung $\mathrm{B}$ kemudian dihisap hingga cairan melewati bagian A dan melewati batas "a".Cairan kemudian dibiarkan mengalir dari batas "a" sampai batas "b".Waktu yang diperlukan sediaan untuk mengalir dihitung menggunakan stopwatch.Pengukuran viskositas diulang masing-masing 3 kali untuk setiap sediaan.Waktu yang diperlukan sediaan untuk mengalir kemudian dihitung viskositasnya.

d. Uji Aktivitas Antibakteri Sediaan Mouthwash Ekstrak Daun Jambu Biji

\section{1) Sterilisasi}

Pada uji antibakteri perlakuan harus dalam keadaan steril, untuk itu semua alat dan bahan yang digunakan harus dalam keadaan steril. Tujuan dari sterilisasi yaitu untuk membunuh mikroorganisme yang ada pada alat dan bahan, karena dikhawatirkan akan mengganggu jalannya penelitian. Sterilisasi dilakukan di dalam autoklaf pada suhu $121^{0} \mathrm{C}$ selama 15 menit.

\section{2) Pembuatan Media Agar Miring}

Sebanyak $5 \mathrm{ml}$ media Mueller Hinton Agar dituangkan masing-masing pada 3 tabung reaksi steril dan ditutup dengan alumunium foil. Media tersebut disterilkan dalam autoklaf pada suhu $121^{0}$ C selama 15 menit, kemudian dibiarkan pada suhu ruangan selama \pm 30 menit sampai media memadat pada kemiringan $30^{\circ}$. Media agar miring digunakan untuk inokulasi bakteri.

\section{3) Pembuatan Media Mueller Hinton Agar (MHA)}

Dimasukkan 3,8 gram media MHA ke dalam erlenmeyer, dilarutkan dengan $100 \mathrm{ml}$ air suling yang diikuti dengan pemanasan dan pengadukan lalu disterilkan di dalam autoklaf pada suhu $121^{0} \mathrm{C}$ selama 15 menit.

4) Inokulasi Bakteri pada Media Agar Miring

Bakteri uji diambil dengan jarum ose steril, lalu ditanamkan pada media agar miring dengan cara menggores. Selanjutnya diinkubasi pada suhu $37^{\circ} \mathrm{C}$ selama 24 jam.

5) Pembuatan Standar Kekeruhan Larutan (Larutan Mc. Farland).

Larutan $\mathrm{H}_{2} \mathrm{SO}_{4} \quad 0,36 \mathrm{~N}$ sebanyak 9,5 ml dicampurkan dengan larutan $\mathrm{BaCl}_{2} 2 \mathrm{H}_{2} \mathrm{O} \quad 1,175 \%$ sebanyak $0,5 \mathrm{ml}$ dalam erlenmeyer. Kemudian dikocok sampai terbentuk larutan yang keruh.Kekeruhan ini dipakai sebagai standar kekeruhan suspensi bakteri uji.

6) Pembuatan Suspensi Bakteri Uji

Bakteri uji yang telah diinokulasi diambil dengan jarum ose steril lalu disuspensikan ke dalam tabung yang berisi 2 ml larutan $\mathrm{NaCl}$ 0,9\% hingga diperoleh kekeruhan yang sama dengan standar kekeruhan larutan Mc. Farland. Perlakuan yang sama dilakukan pada setiap jenis bakteri uji.

7) Perendaman paper disc pada mouthwash

Disiapkan 5 cawan petri untuk proses perendaman paper disc, cawan I diisi dengan mouthwash konsentrasi ekstrak daun jambu biji 2,5\%, cawan II diisi dengan mouthwash konsentrasi ekstrak 3\%, cawan III diisi dengan mouthwash konsentrasi ekstrak 3,5\%, cawan IV diisi dengan mouthwash kontrol negatif (tanpa ekstrak daun jambu biji), dan cawan $\mathrm{V}$ diisi dengan kontrol positif (Mouthwash komersial). Paper disc yang akan digunakan direndam ke dalam keseluruhan cawan petri selama 30 menit kemudian dikeringkan untuk 
selanjutnya digunakan pada pengujian aktivitas antibakteri terhadap Streptococcus mutans.

\section{8) Uji Aktivitas Antibakteri dengan Metode Difusi}

Siapkan 5 cawan petri, dituang medium MHA sebanyak $\pm 15 \mathrm{ml}$ kedalam masing-masing cawan petri, kemudian dihomogenkan dan dibiarkan memadat. Dicelupkan lidi kapas steril kedalam suspensi bakteri Streptococcus mutans, ditunggu sebentar supaya cairan dapat meresap kedalam kapas, kemudian lidi diangkat dan diperas dengan menekankan pada dinding tabung bagian dalam sambil di putar-putar. Diusapkan pada permukaan medium MHA sampai seluruh permukaan tertutup rapat. Dibiarkan selama 5-15 menit supaya suspensi bakteri meresap kedalam agar. Selanjutnya ditempelkan disk yang telah direndam dalam mouthwash ekstrak daun jambu biji dengan konsentrasi 2,5\%, 3\%, dan $3,5 \%$.

Kontrol negatif digunakan disk yang telah direndam pada mouthwash yang tidak mengandung ekstrak daun jambu biji sedangkan untuk kontrol positif digunakan disk yang telah direndam dalammouthwash komersial.Pengulangan dilakukan sebanyak 3 kali. Lalu cawan petri diinkubasi selama 24 jam pada suhu $37^{\circ} \mathrm{C}$. Kemudian diukur diameter zona hambat ( $\mathrm{mm})$ dari masing-masing konsentrasi sampel dengan menggunakan penggaris.

\section{Analisis Data}

Analisis data yang digunakan adalah analisis data kualitatif dan kuantitatif. Analisis data kualitatif berupa data deskriptif dan diaplikasikan dalam bentuk tabel dan grafik yang diperoleh dari pengamatan langsung oleh peneliti terhadap uji organoleptis, uji $\mathrm{pH}$ (derajat keasaman) dan uji viskositas. Analisis data kuantitatif diperoleh dari analisis data terhadap uji aktivitas antibakteri menggunakan metode statistik One Way Anova.

\section{HASIL DAN PEMBAHASAN}

\section{Formulasi Mouthwash Ekstrak Daun Jambu Biji (Psidium guajava L.)}

Pada penelitian sebelumnya telah terbukti bahwa ekstrak daun jambu biji dapat menghambat aktivitas pertumbuhan bakteri Streptococcus mutans, yaitu bakteri penyebab plak gigi [8]. Pada formulasi ini, konsentrasi ekstrak daun jambu biji dibuat bervariasi, yaitu 2,5\%, $3 \%$, dan 3,5\%. Variasi konsentrasi tersebut didasarkan pada penelitian Adi, dkk (2012) [8]. Hasil yang diperoleh dari penelitian tersebut membuktikan bahwa pada konsentrasi 3,5\% merupakan kadar bunuh minimum dari ekstrak daun jambu biji terhadap aktivitas antibakteri Streptococcus mutans. Pada pembuatan sediaan mouthwash diperlukan bahanbahan tambahan seperti gliserin, sorbitol, air suling, dan peppermint oil.Formula dibuat berdasarkan pada penelitian sebelumnya, yaitu penelitian yang dilakukan oleh Pradewa (2008) [9]. Pada penelitian sebelumnya digunakan gom arab untuk meningkatkan kelarutan ektstrak. Namun pada formulasi ini gom arab diganti dengan gliserin untuk meningkatkan kelarutan dari ekstrak yang tidak larut sempurna dalam air, karena setelah dilakukan preformulasi dengan menggunakan gom arab akan menghasilkan endapan. Menurut R.A Gennaro (2000) [11], humektan seperti gliserin dan sorbitol digunakan 5-20\% pada mouthwash untuk memberikan sensasi tertentu di mulut. Humektan berfungsi menjaga bahan-bahan mouthwash agar tidak menguap ke udara. 
Selain itu sorbitol juga digunakan untuk memberikan rasa manis pada sediaan. Pada formulasi ini sorbitol diharapkan dapat mengimbangi rasa ekstrak yang kelat (astringent). Rasa kelat tersebut dikarenakan terdapatnya zat tanin pada ekstrak daun jambu biji yang digunakan. Air suling digunakan sebagai pelarut pada sediaan ini.Digunakan peppermint oil pada formulasi ini karena peppermint oilmemiliki aroma dan rasa yang segar dan sedikit pedas di mulut, sehingga dapat meningkatkan sensasi di mulut pada saat sediaan mouthwash digunakan.

\section{Evaluasi Sediaan Mouthwash Ekstrak Daun Jambu Biji (Psidium guajava $\mathbf{L}$.)}

\section{a. Pengamatan Organoleptis}

Pemeriksaan organoleptis terhadap sediaan mouthwash ekstrak daun jambu biji, meliputi pemeriksaan terhadap warna, aroma, dan rasa.Ketiga parameter tersebut merupakan ciri visual dan karakteristik fisik yang dapatdiamati secara langsung [9]. Hasil dari pengamatan uji organoleptis sediaan mouthwash ekstrak daun jambu biji selama 3 minggu penyimpanan dapat dilihat pada tabel 2 .

Tabel 1. Formula sediaan mouthwash

\begin{tabular}{ccccc}
\hline \multirow{2}{*}{ Komposisi } & Kontrol (-) & Formula 1 & Formula 2 & Formula 3 \\
\cline { 2 - 5 } & - & $2,5 \%$ & $3 \%$ & $3,5 \%$ \\
Ekstrak & 3 & 3 & 3 & 3 \\
Gliserin & 10 & 10 & 10 & 10 \\
Sorbitol & 0,15 & 0,15 & 0,15 & 0,15 \\
Peppermint oil & $a d 100 \mathrm{ml}$ & $\mathrm{ad} 100 \mathrm{ml}$ & $\mathrm{ad} 100 \mathrm{ml}$ & $\mathrm{ad} 100 \mathrm{ml}$ \\
Air suling & & & &
\end{tabular}

Tabel 2. Hasil pengamatan uji organoleptis sediaan mouthwash ekstrak daun jambu biji selama 3 minggu penyimpanan

\begin{tabular}{|c|c|c|c|c|}
\hline Minggu & $\begin{array}{c}\text { Sediaan } \\
\text { Mouthwash }\end{array}$ & Warna & Aroma & Rasa \\
\hline \multirow{3}{*}{1} & $\begin{array}{c}\text { Formula } 1 \\
(\text { Ekstrak 2,5\%) }\end{array}$ & $\begin{array}{l}\text { Hijau } \\
\text { pekat }\end{array}$ & Mint & $\begin{array}{c}\text { Manis, diikuti rasa kelat } \\
\text { khas daun jambu biji }\end{array}$ \\
\hline & $\begin{array}{c}\text { Formula } 2 \\
(\text { Ekstrak 3\%) }\end{array}$ & $\begin{array}{l}\text { Hijau } \\
\text { pekat }\end{array}$ & $\begin{array}{c}\text { Mint, diikuti aroma khas } \\
\text { daun jambu biji }\end{array}$ & $\begin{array}{l}\text { Agak manis, diikuti rasa } \\
\text { kelat khas daun jambu biji }\end{array}$ \\
\hline & $\begin{array}{c}\text { Formula 3 } \\
(\text { Ekstrak 3,5\%) }\end{array}$ & $\begin{array}{l}\text { Hijau } \\
\text { pekat }\end{array}$ & $\begin{array}{c}\text { Mint, diikuti aroma khas } \\
\text { daun jambu biji }\end{array}$ & $\begin{array}{l}\text { Agak manis, diikuti rasa } \\
\text { kelat khas daun jambu biji }\end{array}$ \\
\hline \multirow{3}{*}{2} & $\begin{array}{c}\text { Formula 1 } \\
\text { (Ekstrak 2,5\%) }\end{array}$ & $\begin{array}{l}\text { Hijau } \\
\text { pekat }\end{array}$ & Mint & $\begin{array}{c}\text { Manis, diikuti rasa kelat } \\
\text { khas daun jambu biji }\end{array}$ \\
\hline & $\begin{array}{c}\text { Formula 2 } \\
\text { (Ekstrak 3\%) }\end{array}$ & $\begin{array}{l}\text { Hijau } \\
\text { pekat }\end{array}$ & $\begin{array}{l}\text { Mint, diikuti aroma khas } \\
\text { daun jambu biji }\end{array}$ & $\begin{array}{l}\text { Agak manis, diikuti rasa } \\
\text { kelat khas daun jambu biji }\end{array}$ \\
\hline & $\begin{array}{c}\text { Formula 3 } \\
\text { (Ekstrak 3,5\%) }\end{array}$ & $\begin{array}{l}\text { Hijau } \\
\text { pekat }\end{array}$ & $\begin{array}{l}\text { Mint, diikuti aroma khas } \\
\text { daun jambu biji }\end{array}$ & $\begin{array}{l}\text { Agak manis, diikuti rasa } \\
\text { kelat khas daun jambu biji }\end{array}$ \\
\hline \multirow{3}{*}{3} & $\begin{array}{c}\text { Formula 1 } \\
\text { (Ekstrak 2,5\%) }\end{array}$ & $\begin{array}{l}\text { Hijau } \\
\text { pekat }\end{array}$ & $\begin{array}{c}\text { Mint, diikuti aroma khas } \\
\text { daun jambu biji }\end{array}$ & $\begin{array}{c}\text { Manis, diikuti rasa kelat } \\
\text { khas daun jambu biji }\end{array}$ \\
\hline & $\begin{array}{c}\text { Formula } 2 \\
\text { (Ekstrak 3\%) }\end{array}$ & $\begin{array}{l}\text { Hijau } \\
\text { pekat }\end{array}$ & $\begin{array}{c}\text { Mint lemah, diikuti aroma } \\
\text { khas daun jambu biji }\end{array}$ & $\begin{array}{l}\text { Agak manis, diikuti rasa } \\
\text { kelat khas daun jambu biji }\end{array}$ \\
\hline & $\begin{array}{c}\text { Formula 3 } \\
(\text { Ekstrak 3,5\%) }\end{array}$ & $\begin{array}{l}\text { Hijau } \\
\text { pekat }\end{array}$ & $\begin{array}{l}\text { Mint lemah, diikuti aroma } \\
\text { khas daun jambu biji }\end{array}$ & $\begin{array}{l}\text { Agak manis, diikuti rasa } \\
\text { kelat khas daun jambu biji }\end{array}$ \\
\hline
\end{tabular}


Tabel 3. Nilai pH selama 3 minggu penyimpanan

\begin{tabular}{cccc}
\hline Sediaan & \multicolumn{3}{c}{ Nilai pH } \\
\cline { 2 - 4 } Mouthwash & Minggu 1 & Minggu 2 & Minggu 3 \\
\hline F1 & 5 & 5 & 5 \\
F2 & 5 & 5 & 5 \\
F3 & 5 & 5 & 5 \\
\hline
\end{tabular}

Tabel 2 menunjukkan bahwa warna dari ketiga formulasi tersebut sama, yaitu hijau pekat. Hal ini dikarenakan terdapat kandungan ekstrak daun jambu biji yang digunakan sebagai bahan aktif. Aroma pada formula 1 yang dominan yaitu aroma mint dari bahan tambahan yang digunakan (peppermint oil), sedangkan aroma pada formula 2 dan 3 yaitu mint dan diikuti aroma khas daun jambu biji. Hal ini dikarenakan kandungan ekstrak daun jambu biji pada formula 2 dan 3 lebih besar dari formula 1 , semakin besar kandungan ekstrak daun jambu biji maka aroma khas dari daun jambu biji akan semakin tercium. Terdapat perbedaan rasa antara formula 1, 2 dan 3 dikarenakan konsentrasi sorbitol yang digunakan sebagai bahan pemanis pada formulasi 1, 2, dan 3 sama yaitu $10 \%$, sedangkan konsentrasi ekstrak daun jambu biji yang memiliki rasa kelat pada formula 1, 2, dan 3 berbeda. Diketahui bahwa semakin besar konsentrasi ekstrak maka rasa kelat dari ekstrak daun jambu biji akan semakin terasa.

Hasil pengamatan selama 2 minggu penyimpanan tidak terjadi perubahan pada ketiga formulasi tersebut terhadap warna, aroma, dan rasa, namun terjadi perubahan pada minggu ketiga terhadap aroma dari ketiga formulasi tersebut.Hal ini dapat dipengaruhi karena tidak adanya penambahan bahan penstabil sediaan (pengawet) sehingga dapat menurunkan stabilitas sediaan mouthwash.

\section{b. Uji pH}

Nilai $\mathrm{pH}$ suatu medium sangat mempengaruhi jenis bakteri yang dapat tumbuh. Kebanyakan bakteri mempunyai $\mathrm{pH}$ optimum yaitu sekitar $\mathrm{pH}$ 6,5-7,5 [10]. Oleh karena itu, nilai $\mathrm{pH}$ dari formulasi mouthwash ekstrak daun jambu biji harus berada diluar range nilai $\mathrm{pH}$ optimum pertumbuhan bakteri, mengingat sifat formulasi mouthwash yang diinginkan bersifat antibakteri.Selain itu, $\mathrm{pH}$ pada mouthwash berkisar antara 5,71-5,98 [9].

Pengujian $\mathrm{pH}$ sediaan mouthwash ekstrak daun jambu biji dilakukan dengan menggunakan indikator $\mathrm{pH}$ universal.Hasil dari pengujian $\mathrm{pH}$ dapat dilihat pada tabel 3 .

Dari tabel 3 dapat diketahui bahwa selama 3 minggu penyimpanan nilai $\mathrm{pH}$ dari ketiga formula tersebut sama, yaitu 5. pH pada sediaan mouthwash ekstrak daun jambu biji cenderung asam, hal ini dipengaruhi oleh $\mathrm{pH}$ dari bahan tambahan yang digunakan yaitu sorbitol dengan $\mathrm{pH} 4,5$ [12]. Dari hasil analisis nilai $\mathrm{pH}$ pada sediaan diketahui bahwa nilai $\mathrm{pH}$ berada diluar range $\mathrm{pH}$ optimum pertumbuhan bakteri, sehingga formulasi mouthwash ekstrak daun jambu biji ini dapat menghambat pertumbuhan bakteri yang ada di rongga mulut, terutama bakteri Streptococcus mutans yang merupakan penyebab utama penyakit karies gigi. 


\section{c. Uji Viskositas}

Viskositas suatu formulasi mouthwash sangat mempengaruhi terhadap tingkat kekentalan produk tersebut saat digunakan berkumur di dalam mulut. Semakin dekat tingkat viskositas suatu produk formulasi mouthwash dengan tingkat viskositas air, maka semakin mudah dan nyaman produk tersebut digunakan untuk berkumur. Viskositas air sebagai standar pada perhitungan viskositas adalah sekitar $\pm 1 \mathrm{cP}$.Hasil pengujian viskositas sediaan mouthwash sebesar 1,27-1,82 cP [9]. Hasil dari pengujian viskositas dapat dilihat pada tabel 4 .

Hasil analisis viskositas pada minggu pertama menunjukkan bahwa nilai viskositas dari formulasi mouthwash ekstrak daun jambu biji berkisar antara $1,328-1,347 \mathrm{cP}$, nilai viskositas tertinggi dimiliki formula 3 yaitu formulasi dengan konsentrasi ekstrak tertinggi 3,5\% dan nilai viskositas terendah didapat pada formula 1 yaitu formulasi dengan konsentrasi ekstrak terkecil 2,5\%.

Hasil analisis dapat diketahui bahwa nilai viskositas mouthwash ekstrak daun jambu biji memiliki nilai lebih besar dibandingkan dengan nilai viskositas air, namun nilai viskositas tersebut masih memenuhi persyaratan karena berada dalam range viskositas mouthwash. Jika melihat tabel 6 maka dapat diketahui bahwa semakin besar konsentrasi ekstrak yang digunakan maka akan semakin besar pula nilai viskositasnya. Hal ini disebabkan karena penggunaan ekstrak daun jambu biji yang terdiri atas partikelpartikel halus terlarut, sehingga dapat meningkatkan nilai viskositas pada mouthwash yang dihasilkan. Selain ekstrak, bahan tambahan yang digunakan seperti gliserin dan sorbitol juga mempengaruhi viskositas sediaan. Menurut Rowe, dkk., (2009) [12] gliserin memiliki nilai viskositas sebesar $1,143 \mathrm{cP}$ pada konsentrasi $5 \%$ dan sorbitol memiliki nilai viskositas sebesar $1,2 \mathrm{cP}$ pada konsentrasi $10 \%$.

Penyimpanan minggu kedua dan minggu ketiga terjadi penurunan nilai viskositas. Hal ini disebabkan karena kandungan air yang besar pada sediaan mouthwash ekstrak daun jambu biji yang dapat menimbulkan tumbuhnya jamur dan tidak adanya bahan penstabil sediaan (pengawet), sehingga stabilitas fisik sediaan dapat menurun. Pada formula ini tidak digunakan bahan pengawet dikarenakan pada penelitian ini dilakukan uji aktivitas antibakteri yang jika diberi bahan pengawet dikhawatirkan akan mempengaruhi hasil dari uji aktivitas antibakteri tersebut.

\section{d. Uji Aktivitas Antibakteri Sediaan Mouthwash Ekstrak Daun Jambu Biji Terhadap Streptococcus mutans} Pengujian aktivitas antibakteri Streptococcus mutans dilakukan dengan 3 formula mouthwash yang berbeda dan 2 kontrol. Tiga formula tersebut yaitu formula 1 dengan konsentrasi ekstrak $2,5 \%$, formula 2 dengan konsentrasi ekstrak 3\%, dan formula 3 dengan konsentrasi ekstrak 3,5\%. Dua kontrol yang digunakan ialah kontrol negatif (tanpa ekstrak) dan kontrol positif yang menggunakan mouthwash komersial yang sudah beredar di pasaran.

Pengujian ini dilakukan untuk mengetahui pengaruh mouthwash ekstrak daun jambu biji yang dihasilkan terhadap Streptococcus mutans. Mouthwash ekstrak daun jambu biji ditujukan sebagai alternatif mouthwash berbahan dasar alami dan tanpa alkohol. Streptococcus mutans dipilih sebagai bakteri uji karena bakteri tersebut merupakan bakteri rongga mulut yang utama sebagai penyebab penyakit karies gigi.

Pengujian aktivitas antibakteri dilakukan dengan metode difusi agar 
yaitu metode pengujian dimana senyawa antimikroba dimasukkan ke dalam agar melalui kertas cakram. Komponen akan berdifusi ke dalam agar dan menghambat pertumbuhan mikroba yang terkandung dalam agar. Selanjutnya, diinkubasi selama 24 jam pada suhu $37^{0}$ C. Setelah 24 jam diinkubasi dilakukan pengamatan dan pengukuran zona atau diameter penghambatan pertumbuhan mikroba $(\mathrm{mm})$ yang ditandai dengan adanya area bening yang menunjukkan tidak adanya pertumbuhan mikroba uji.

Terbentuknya area bening disekitar kertas cakram pada uji aktivitas antibakteri ini membuktikan bahwa ekstrak daun jambu biji yang diformulasikan ke dalam sediaan mouthwash memiliki sifat antibakteri terhadap Streptococcus mutans. Hasil pengukuran zona hambat terhadap Streptococcus mutans dapat dilihat pada tabel 5.

Tabel 4. Pengukuran viskositas selama 3 minggu penyimpanan

\begin{tabular}{cccc}
\hline Sediaan & \multicolumn{3}{c}{ Viskositas (cP) } \\
\cline { 2 - 4 } Mouthwash & Minggu 1 & Minggu 2 & Minggu 3 \\
\hline F1 & $1.328 \pm 0.003$ & $1.313 \pm 0.005$ & $1.276 \pm 0.002$ \\
F2 & $1.338 \pm 0.004$ & $1.325 \pm 0.002$ & $1.286 \pm 0.001$ \\
F3 & $1.347 \pm 0.002$ & $1.330 \pm 0.002$ & $1.296 \pm 0.001$ \\
\hline
\end{tabular}

Tabel 5. Hasil pengukuran zona hambat ( $\mathrm{mm}$ ) terhadap Streptococcus mutans

\begin{tabular}{cccccc}
\hline \multirow{2}{*}{ Pengulangan } & \multicolumn{5}{c}{ Diameter Zona Hambat (mm) } \\
\cline { 2 - 6 } I & F1 & F2 & F3 & K (-) & K (+) \\
\hline II & 2,45 & 3,6 & 3,85 & 0 & 1,20 \\
III & 2,95 & 3,75 & 4,30 & 0 & 1,75 \\
\hline Rata-rata & 3,05 & 4,15 & 4,80 & 0 & 1,90 \\
\hline Keterangan : & 3,83 & 4,32 & 0 & 1,62 \\
F1 : mouthwash dengan konsentrasi ekstrak 2,5\% \\
F2 : mouthwash dengan konsentrasi ekstrak 3\% \\
F3 : mouthwash dengan konsentrasi ekstrak 3,5\% \\
K (-) : kontrol negative \\
\multicolumn{7}{c}{ K (+) } & $:$ kontrol positif
\end{tabular}

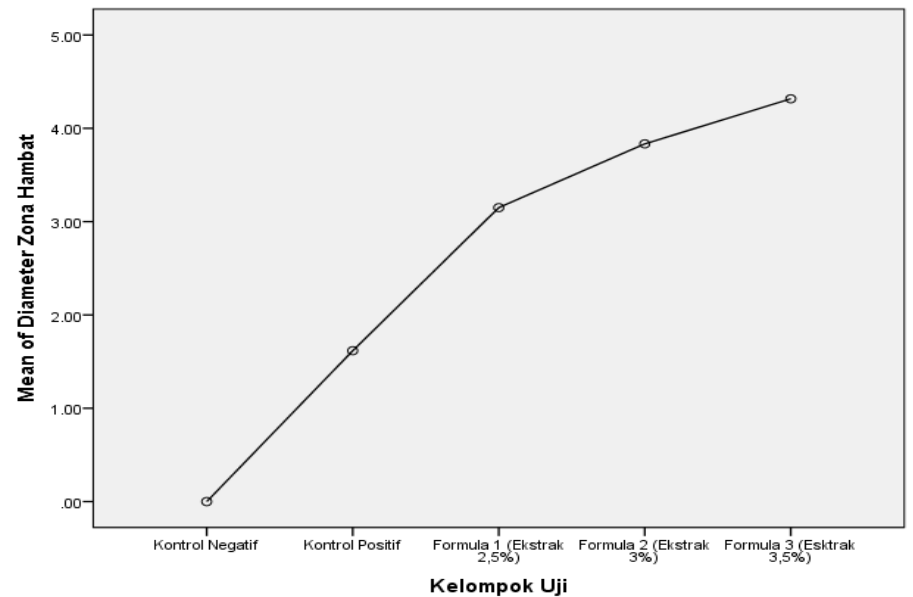

Gambar 1. Grafik Zona Hambat terhadap Streptococcus mutans 
Formulasi Dan Uji Aktivitas Antibakteri Streptococcus Mutans Dari Sediaan Mouthwash Ekstrak Daun Jambu Biji (Psidium Guajava L.)

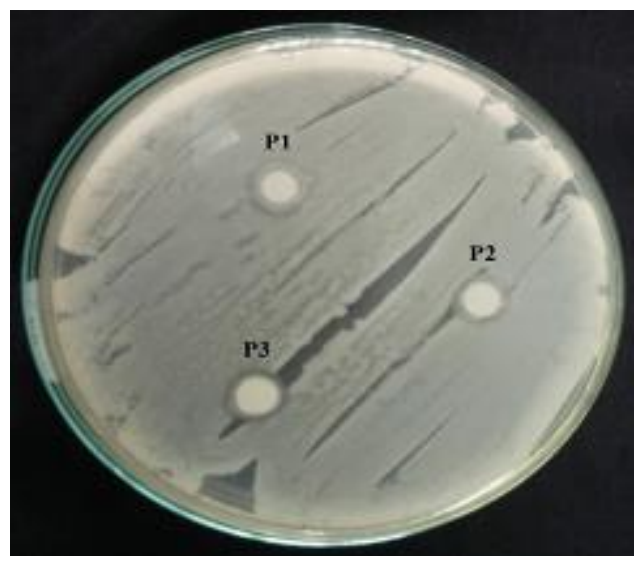

$\mathrm{a}$

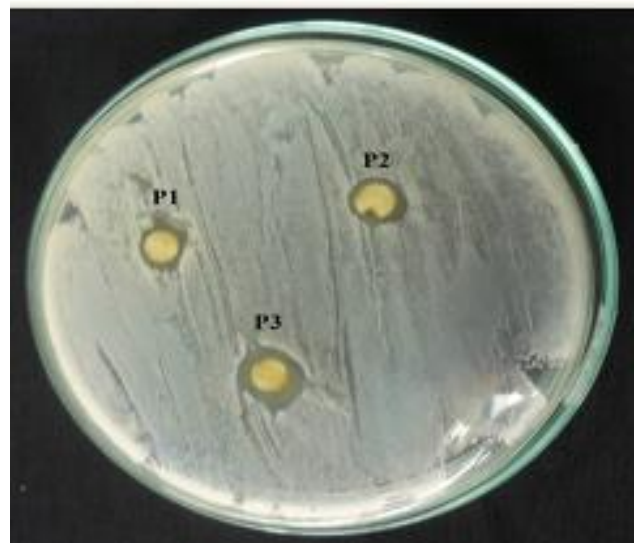

$\mathrm{C}$

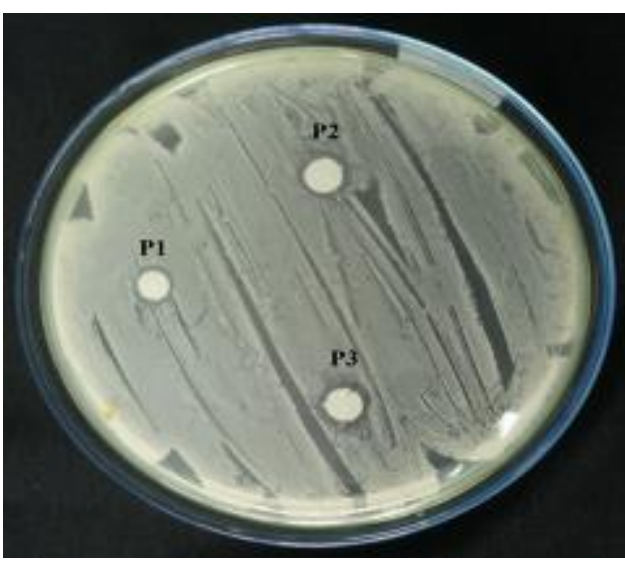

b

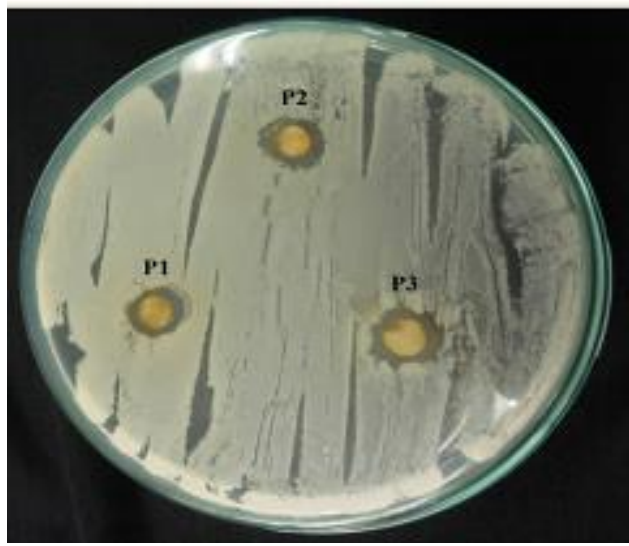

d

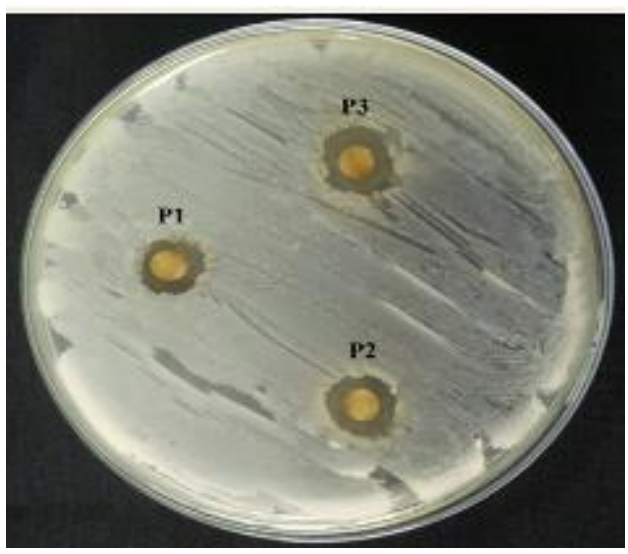

$\mathrm{e}$

Gambar 2. Hasil Uji Aktivitas Antibakteri terhadap Streptococcus mutans

\section{Keterangan :}

$a=$ zona hambat pada kontrol negatif

$\mathrm{c}=$ zona hambat pada formula 1

$\mathrm{e}=$ zona hambat pada formula 3 $b=$ zona hambat pada kontrol positif

$\mathrm{d}=$ zona hambat pada formula 2 
Data yang diperoleh pada tabel 6 dan gambar 1 diketahui bahwa ketiga formulasi mouthwash tersebut mampu menghambat Streptococcus mutans yaitu mouthwash dengan konsentrasi ekstrak daun jambu biji sebanyak 2,5\%, 3\% dan $3,5 \%$. Semakin besar konsentrasi ekstrak di dalam formulasi sediaan mouthwash, maka semakin besar pula daya hambat yang dihasilkan. Daya hambat menurut Davis dan Stous (1971) [13] dibagi atas, sangat kuat (zona jernih > $20 \mathrm{~mm}$ ), kuat (zona jernih 10-20 mm), sedang (zona jernih 5-10 mm), dan lemah (zona jernih < $5 \mathrm{~mm}$ ). Mouthwash dengan konsentrasi ekstrak 2,5\% menghasilkan zona hambat sebesar 3,15 mm, mouthwash dengan konsentrasi ekstrak 3\% menghasilkan zona hambat sebesar $3,83 \mathrm{~mm}$, dan mouthwash dengan konsentrasi ekstrak 3,5\% menghasilkan zona hambat sebesar 4,32 $\mathrm{mm}$, sehingga kemampuan menghambat yang dihasilkan oleh mouthwash ekstrak daun jambu biji terhadap Streptococcus mutans dapat dikategorikan lemah. Kontrol negatif yang digunakan tidak memperlihatkan daya hambat terhadap Streptococcus mutans. Kontrol negatif berupa mouthwash tanpa adanya ekstrak daun jambu biji sebagai zat aktif. Pada kontrol positif (mouthwash komersial) menunjukkan adanya aktivitas antibakteri Streptococcus mutans dengan diameter zona hambat sebesar 1,62 mm.zona hambat bakteri dapat dilihat pada gambar 2.

Senyawa kimia yang terkandung di dalam ekstrak daun jambu biji yang berperan sebagai antibakteri ialah tanin, flavonoid, dan saponin. Mekanisme kerja tanin sebagai antibakteri adalah mengganggu sintesa peptidoglikan sehingga pembentukan dinding sel menjadi kurang sempurna. Keadaan tersebut akan menyebabkan sel bakteri menjadi lisis karena tekanan osmotik maupun fisik sehingga sel bakteri menjadi mati. Mekanisme kerja flavonoid sebagai antibakteri adalah membentuk senyawa kompleks dengan protein ekstraseluler dan terlarut yang mengakibatkan fosfolipid tidak mampu mempertahankan bentuk membran sel bakteri, akibatnya membran sel akan bocor dan bakteri akan mengalami hambatan pertumbuhan bahkan kematian. Mekanisme kerja saponin sebagai antibaktei adalah menurunkan tegangan permukaan sehingga mengakibatkan naiknya permeabilitas atau kebocoran sel dan mengakibatkan senyawa intraseluler akan keluar [14].

Hasil analisis statistik menggunakan One-Sample KolmogorovSmirnov Test dan One Way Anova diketahui bahwa data homogen dan terdistribusi normal. Pada kontrol negatif terdapat perbedaan bermakna terhadap kontrol positif dan terhadap formula 1, 2, dan 3. Pada kontrol positif terdapat perbedaan bermakna terhadap formula 1 , 2, dan 3 .

Data di atas, maka dapat disimpulkan bahwa daya hambat terhadap bakteri Streptococcus mutans dari mouthwash ekstrak daun jambu biji lebih besar dibandingkan dengan daya hambat dari kontrol positif.

\section{KESIMPULAN}

1. Ekstrak daun jambu biji (Psidium guajava L.) dapat diformulasikan ke dalam sediaan mouthwash yang memenuhi persyaratan fisik meliputi, uji $\mathrm{pH}$ dan uji viskositas, tetapi tidak memenuhi uji organoleptis.

2. Adanya perbedaan aktivitas antibakteri terhadap pertumbuhan Streptococcus mutans sediaan mouthwash ekstrak daun jambu biji dengan variasi konsentrasi ekstrak yakni konsentrasi 2,5\% sebesar 3,15 
mm, konsentrasi $3 \%$ sebesar 3,83 $\mathrm{mm}$, dan konsentrasi $3,5 \%$ sebesar $4,32 \mathrm{~mm}$.

\section{DAFTAR PUSTAKA}

[1]. Kidd, E.A.M. dan S.J. Bechal. 1992. Dasar-Dasar Karies: Penyakit dan Penanggulangannya. Terjemahan Narlan Sumawinata \& Safrida Faruk. EGC. Jakarta.

[2]. Roeslan, B.O. 1996. Karakteristik Streptococcus mutans Penyebab Karies Gigi. Majalah Ilmiah Kedokteran Gigi FKG Usakti.

[3]. Departemen Kesehatan RI. 2014. Laporan Nasional Riset Kesehatan Dasar 2013. Departemen Kesehatan RI. Jakarta.

[4]. Mc Cullough, MJ dan Farah CS. 2008.The role of alcohol in oral carsinogenesis with particular reference to alcohol-containing mouthwashes. Australian Dental Journal.

[5]. Geidam, Y.A., A.G. Ambali dan P.A. Onyeyili. 2007. Preliminary phytochemical and antibacterial evaluation of crude aqueous extract of Psidium guajava leaf. J. Applied Sci.

[6]. Jayanti, M.F. 2011. Perbedaan Daya Hambat Ekstrak Daun Jambu Biji (Psidium Guajava L.) Varian Merah dan Putih Terhadap Pertumbuhan Streptococcus mutans dan Staphylococcus aureus.Skripsi.Program Studi Biologi Fakultas Keguruan dan Ilmu Pendidikan Biologi. Universitas Jember.
[7]. Adnyana, I.K, Elin Y, Sigit, Joseph I, Fisheri, Neng K, dan M. Insanu.2004. Efek Ekstrak Daun Jambu Biji Daging Buah Putih dan Jambu Biji Daging Buah Merah Sebagai Antidiare.Acta. Phar. Ind. Vol. XXIX.

[8]. Adi, P, Noorhamdani, dan Rian Hermawan. 2012. Uji Aktivitas Ekstrak Daun Jambu Biji (Psidium guajava Linn.) Sebagai Antimikroba Terhadap Bakteri Penyebab Karies Streptococcus mutans Secara In Vitro. Skripsi. Program Studi Pendidikan Dokter Gigi Fakultas Kedokteran. Universitas Brawijaya.

[9]. Pradewa, M.R. 2008. Formulasi Sediaan Obat Kumur Berbahan Dasar Gambir (Uncaria gambier Roxb). Skripsi. Fakultas Teknologi Pertanian. Institut Pertanian Bogor.

[10]. Fardiaz, S. 1989. Mikrobiologi Pangan. Direktorat Jenderal Pendidikan Tinggi Pusat Antar Universitas IPB. Bogor.

[11]. Gennaro, R.A. 2000. Remington: The Science and Practice of Pharmacy. 20th Edition. Lippincott Williams \& Wilkins. New York.

[12]. Rowe, R.C., P.J. Sheskey, dan M.E. Quinn. 2009. Handbook of Pharmaceutical Excipients, $6^{\text {th }}$ Edition. Pharmaceutical Press. London.

[13]. Davis, W.W dan Stous T.R. 1971. Disc Plate Methods of Microbiological Antibiotic Assay. Microbiology.

[14]. Robinson, T. 1995. Kandungan Organik Tumbuhan Tinggi. Terjemahan : Kosasih Padmawinata. Penerbit ITB. Bandung. 